\title{
Immunomodulatory Effects of $L P S$ (E. coli lipopolysaccharide) in Infectious Repeat Breeder Crossbred Cows
}

\author{
Bhardwaz, Anavil ${ }^{1}$, S.P. Nema ${ }^{2}$, S.S. Mahour ${ }^{2}$, Bagati, Sreshti ${ }^{3}$ \\ and Kumar and Sudershan ${ }^{2 *}$ \\ ${ }^{1}$ Department of Veterinary clinical complex, Khalsa Veterinary College, Amritsar, India \\ ${ }^{2}$ College of Veterinary Science and A.H., N.D.V.S.U., Mhow (M.P.), India \\ *Corresponding author
}

\begin{abstract}
A B S T R A C T
Keywords

Repeat breeders, Uterine flushing, LPS, Bacterial count, Total cellular count, PMNs\% Conception rate

Article Info

Accepted:

22 October 2018

Available Online:

10 Novemher 2018

The present study was undertaken to evaluate the therapeutic efficacy of LPS ( $E$. coli lipopolysaccharide) in 20 infectious repeat breeder crossbred cows brought to the AI centre of Department of Veterinary Gynaecology and Obstetrics of College of Veterinary Science and Animal Husbandry, Mhow and in nearby Government AI centres. Animals were divided into two groups of ten in each. The animals in first group were treated with intrauterine infusion of $100 \mu \mathrm{g}(L P S)$ E. coli lipopolysacharide in $30 \mathrm{ml}$ phosphate buffer saline (PBS) on day of estrum only. The animals in control group were infused with $30 \mathrm{ml}$ saline IU, at $24 \mathrm{hrs}$ interval, for 7 days. The mean values of bacterial count in uterine flushing declined significantly $(\mathrm{P}<0.05)$ after treatment in LPS group (from $318.85 \pm 0.16$ to $\left.1.12 \pm 0.07 \times 10^{4} / \mathrm{ml}\right) \quad$ A significant increase $(\mathrm{p}<0.05)$ in mean values of total Cellular count $\left(\times 10^{6} / \mathrm{ml}\right)$ from $1.20 \pm 0.00$ to $7.65 \pm 0.05$ and mean values of PMNs \% from $26.81 \pm 0$ to $59.93 \pm 0.22$ was in LPS group than in control group. An overall recovery rate of 70.00 per cent and conception rate of 60.00 per cent was found in LPS treated repeat breeder cross bred cows.
\end{abstract}

\section{Introduction}

One calf a year by cow is essential for economic viability in dairying. The major hindrance is suboptimal reproductive rhythm to achieve this target. It requires that the cows must get pregnant within a maximum service period of 90-95 days post-partum. In this context, repeat breeder cows are those that have normal or near normal estrous cycle and estrus period, has been served /inseminated with fertile bull two or more times yet failed to conceive (Roberts, 1971). Repeat breeding, comprise a heterogeneous group of subfertile cows with a tune of 7.31 to $23.88 \%$ among bovines (Singh, 1991). Though, antibiotics are quite effective in treating endometritis, but use of immunomodulator is becoming popular due to toxicity and side effects of allopathic medicines. Immunomodulators such as E. coli lipopolysaccharides ( $E$. coli LPS) have been found effective for the treatment of subclinical and clinical endometritis (Husain and Daniel, 1992; Saini et al., 1999 and Kumar, 2010). 
The present study was undertaken to evaluate the therapeutic efficacy of LPS (E. coli lipopolysaccharide) in infectious repeat breeder crossbred cows.

\section{Materials and Methods}

The study was conducted on clinical cases of endometritis in crossbred cows belonging to farmers brought to the AI centre of Department of Veterinary Gynaecology and Obstetrics of the College of Veterinary Science and A.H. Mhow (India) and nearby Government AI centres during period from December 2015 to April 2017. All the cows (> 90 days postpartum) were screened as per history, gynaecological examination, nature of estrual cervico-vaginal mucus and positive to white side test (WST) as per method of Popov (1969) to identify them as infectious repeat breeding crossbred cows. These crossbred cows were classified as repeat breeders based on cycling normally without any apparent genital abnormalities and repeated estrus after three or more consecutive services. The infectious repeat breeder cows thus identified were divided into two groups with ten animals in each, (T1 treatment group and T2 was kept as negative control).

Animals of T1 group were treated with intrauterine infusion of $100 \mu \mathrm{g}(L P S) E$. coli lipopolysacharidein $30 \mathrm{ml}$ phosphate buffer saline (PBS) on day of estrum only, whereas animals of control group were infused $30 \mathrm{ml}$ saline for 7 days as placebo. The estrual cervico-vaginal mucus was examined for $\mathrm{pH}$ before and after treatment at subsequent estrus using $\mathrm{pH}$ paper strips. All animals (T1 and T2) were flushed before start of the therapy and after 24 hours of administration of the LPS and saline and 8-12 hours after they showed first signs of heat. Total bacterial count in uterine flushing was done as per Bauer et al., (1966). Total cellular count in the uterine flushing was determined by haemocytometeric technique (Jain, 1986). Polymorphonuclear (PMNs \%) cell count in the uterine flushing was made in smears prepared from the cell suspension received by centrifugation (3000 rpm for five minutes) on clean grease free glass slides, and stained with Giemsa stain (Kasimanickam et al., 2004). Statistical analysis was carried out by using completely randomized design as per Snedecore and Cochran (1980).

\section{Results and Discussion}

The observations on the nature of the CVM revealed that during infection purulent discharge was observed in $40 \%$ cows and muco-purulent discharge in $50 \%$ cows, whereas the CVM of $10 \%$ cows was clear. Any alteration in the colour of estrual mucus will indicate genital infections (Bhat et al., 2015). Following intrauterine infusion of LPS, the discharge at subsequent estrus was observed as clear in $70 \%$ cows in comparison to untreated control group (10\%). Saini et al., (1999) and Deori et al., (2004) stated that cloudy, milky and turbid cervical discharge became clear at the time of subsequent oestrus in 78 per cent cows treated with E.Coli LPS, whereas, Shaktawat et al., (2006) reported that 87.71 per cent cows showed clear discharge after treatment with LPS followed by antibiotic group (71.43 per cent) in comparison to untreated control group (28.57 per cent). Desai (2017) reported clear discharge in 70.00 per cent of crossbred cows after treatment with E.coli LPS which is in agreement with the present findings. The clear estrual cervical mucus after treatment may be due to stimulation of uterine defense mechanism, increased phagocytosis and finally elimination of infection.

In the present study, the higher values of $\mathrm{pH}$ in repeat breeder cows are in close proximity to the values reported earlier (Modi et al., 2011; Sudarshan Kumar et al., 2015 and Bhardwaz 
et al., 2018). In repeat breeding cows with endometritis due to infection, the metabolites of bacteria and inflammatory exudates may alter the $\mathrm{pH}$ of estrual cervical mucus to alkaline side resulting in failure of conception due to death of spermatozoa (Ravikumar et al., 2007; Bhardwaz et al., 2018). Once the infection is eliminated, the $\mathrm{pH}$ of cervical mucus returns towards the normal neutral side.

White side test (WST) was performed on the estrual cervico-vaginal mucus of control and treated animals, before and after treatment. Most of the cows became negative to White side test following treatment with LPS (70.00\%) as compared to only $20.00 \%$ cows in control group which reveals that the LPS was most effective treatment for endometritis. The present findings corroborated with earlier study (Singh, 2016 and Bhardwaz et al., 2018).

A significant decline $(\mathrm{p}<0.05)$ in bacterial count $\left(\times 10^{4} / \mathrm{ml}\right)$ was observed from pretreatment to post-treatment estrus in uterine flushing of LPS group (318.85 \pm 0.16 to $1.12 \pm$
0.07) as compared to control group (328.62 \pm 0.17 to $296.96 \pm 0.22)$. The per cent reduction was highest in LPS than in control group. Keeping in pace with these results, Prasad (2006) and Kumar (2010) reported significant drop in bacterial load in uterine flushing following treatment with LPS. This reduced bacterial count might be due to increased influx of neutrophils in the uterine lumen and subsequent phagocytosis of viable bacteria (Klucinski et al., 1990 and Hussain and Daniel, 1992). Further, significantly lower bacterial count was observed in treatment involving LPS indicating higher efficacy of treatment in eliminating bacteria. In control group, it remained elevated. Reduction in bacterial load in control group may be due to natural uterine defense mechanisms. Besides this, uterine flushings might have also reduced bacterial load. A significant increase $(\mathrm{p}<0.05)$ in the total cellular count $\left(10^{4} / \mathrm{ml}\right)$ and $(\mathrm{PMNs})$ $\%$ values was observed from pre-treatment to post- treatment in uterine flushing of LPS group $(1.20 \pm 0.00$ to $7.65 \pm 0.05)$ and $(26.81 \pm 0.25$ to $59.93 \pm 0.22)$, respectively (Table 1 and 2).

Table.1 Immunomodulatory effects of LPS (E. coli lipopolysaccharide) on CVM, pH, white side test, bacterial count, total cellular count and PMN (\%) in infectious repeat breeder crossbred cows

\begin{tabular}{|c|c|c|c|c|c|}
\hline \multirow{2}{*}{\multicolumn{2}{|c|}{ Parameters/Observations }} & \multirow{2}{*}{\multicolumn{2}{|c|}{$\operatorname{LPS}(\mathbf{n}=10)$}} & \multirow{2}{*}{\multicolumn{2}{|c|}{ Control $(\mathrm{n}=10)$}} \\
\hline & & & & & \\
\hline \multirow{3}{*}{$\begin{array}{l}\text { CVM } \\
\text { appearance }\end{array}$} & Purulent & $40.00(4)$ & $20.00(2)$ & 6000 (6) & $5000(5)$ \\
\hline & $\begin{array}{l}\text { Muco- } \\
\text { purulent }\end{array}$ & $50.00(5)$ & $10.00(1)$ & $40.00(4)$ & $40.00(4)$ \\
\hline & Clear & $10.00(1)$ & $70.00(7)$ & 0.00 & $10.00(1)$ \\
\hline \multirow{2}{*}{$\begin{array}{l}\text { White side } \\
\text { test }\end{array}$} & Positive & $100.00(10)$ & $30.00(3)$ & $100.00(10)$ & $80.00(8)$ \\
\hline & Negative & 0.00 & $70.00(7)$ & 0.00 & $20.00(2)$ \\
\hline \multicolumn{2}{|c|}{ CVM -pH (Mean \pm SE $)$} & $8.18 \pm 0.01^{\mathrm{A}}$ & $7.70 \pm 0.01^{B}$ & $8.36 \pm 0.02^{X}$ & $8.31 \pm 0.02^{Y}$ \\
\hline \multicolumn{2}{|c|}{ Bacterial count $\left(10^{4} / \mathrm{ml}\right)$} & $318.85 \pm 0.16^{\mathrm{A}}$ & $1.12 \pm 0.07^{\mathrm{B}}$ & $328.62 \pm 0.17$ & $296.96 \pm 0.22$ \\
\hline \multicolumn{2}{|c|}{ Total cellular count (TCC) } & $1.20 \pm 0.00^{\mathrm{A}}$ & $7.65 \pm 0.05^{\mathrm{B}}$ & $0.433 \pm 0.02^{X}$ & $0.581 \pm 0.01^{Y}$ \\
\hline \multicolumn{2}{|c|}{ PMNs (\%) } & $26.81 \pm 0.25^{\mathrm{A}}$ & $59.93 \pm 0.22^{\mathrm{B}}$ & $27.84 \pm 0.12$ & $25.57 \pm 0.27$ \\
\hline
\end{tabular}

Means bearing different superscripts within the row for a group differ significantly $(\mathrm{p}<0.05)$. 
Table.2 Recovery rate and conception rate in different groups of infectious repeat breeding crossbred cows after treatment

\begin{tabular}{|l|c|c|c|c|c|c|}
\hline \multicolumn{1}{|c|}{ Groups } & No. of & Recovery & \multicolumn{4}{|c|}{ Conception rates (\%) } \\
\cline { 5 - 8 } & cows & rate (\%) & $1^{\text {st }} \mathrm{AI}$ & $2^{\text {nd }} \mathrm{AI}$ & $3^{\text {rd }} \mathrm{AI}$ & Overall \\
\hline LPS & 10 & $70.00(7)$ & $40.00(4)$ & $10.00(1)$ & $10.00(1)$ & $60.00(6)$ \\
\hline Control & 10 & $20.00(2)$ & -- & $10.00(1)$ & -- & $10.00(1)$ \\
\hline
\end{tabular}

A non- significant change was found in TCC in control cows after normal saline infusion. The non-significant increase in cellular count in control group might be due to natural uterine defense mechanism. The increase in cellular count in control group might be due to natural uterine defense mechanism. The present findings are in agreement with the earlier reports (Singh, 1996 and Prasad, 2006) of rise in cellular count starting from $12 \mathrm{~h}$ up to $72 \mathrm{~h}$ after LPS and OG treatment. Similar findings were recorded by Hussain and Daniel (1992); Singh et al., (2001) and Deori (2002) in cows. This type of leucocytosis in the uterus with intrauterine $E$. coli LPS was also observed by Saini (1993); Singh (1996); Prasad (2006) and Kumar (2010).

\section{Conception rate and Recovery rate}

After treatment with LPS, $70 \%$ recovery rate and $60 \%$ conception rate was recorded in the present study as compared with control group (20 and $10 \%$ ). Recovery rate was found to be significant $(p<0.05)$. This could be due to the significant reduction of bacterial count in LPS treated animal, as LPS is well known for its increased influx of neutrophils in the uterine lumen and subsequent phagocytosis of viable bacteria (Klucinski et al., 1990 and Hussain and Daniel, 1992).

The present study is in agreement with Kumar (2010) who reported that after treatment with LPS, 75 per cent recovery rate and 62.5 per cent conception rate was recorded as compared with control group 12.5 per cent and 25 per cent, respectively. Significantly better therapeutic effects of E.coli LPS and Lugol's iodine were evident by more number of cows with clear appearance of estrual cervico-vaginal mucus, no colour reaction to White side test, reduction in $\mathrm{pH}$ and bacterial count in uterine flushing and a significantly higher conception rate in comparison to control group cows.

Hussain and Daniel (1992) could successfully control endometritis in cows through a single E.coli LPS infusion which had caused increased influx of PMN and serum proteins resulting in rapid elimination of bacteria through phagocytosis. Saini et al., (1999); Singh et al., (2000); Deori (2002); Prasad (2006) and Kumar (2010) reported similar conception rate following LPS infusion in endometritis. The low conception rate in untreated cows might be due to delay in the spontaneous elimination of infection by natural uterine defense mechanism.

\section{Acknowledgement}

Authors are thankful to Vice Chancellor, NDVSU, Jabalpur and Dean, College of Veterinary Science and $\mathrm{AH}$, Mhow for providing facilities to undertake this study.

Conflict of Interest: All authors declare no conflict of interest. 


\section{References}

Bauer, A.W., Kirby, W.M.M., Sherris, J.C. and Truck, M. (1966). Antibiotic susceptibility testing by a standardized single disk method. Am. J. Clin. Path., 45(4): 493-496.

Bhardwaz, A., Nema, S.P., Sudarshan, K,. Chabbra Daljeet, Shukla, S. and Madhwani, R. (2018). Effect of ciprofloxacin on recovery and conception rate in infectious repeat breeder crossbred cows. Indian J. Vet. Sci. \& Biotech., 14(1): 71-74.

Bhat, F.A., Bhattacharya, H.K..Fazili, M.R., Hussain, S.A. and Khan, M.Z. (2015). Studies on oestrual cervical mucus of repeat breeding cows with special reference to ovularory disturbance and genital infection. Theriogenology, 5(2): 113-123.

Deori, S. (2002). Use of bacterial modulins in treatment of endometritis in cows. M.V.Sc. thesis (Animal Reproduction, Gynaecology and Obstetrics), Indian Veterinary Research Institute, Izatnagar.

Deori, S., Kumar, H., Yadav, M.C., Rawat, M. and Srivastava, S.K. (2004). Intrauterine administration of bacterial modulins: An alternative therapy for endomertritis. Journal of Applied Animal Research, 26(2):117-121.

Desai, S.K.P. (2017). Oestrual mucus and serum biochemical profiles of endometritic repeat breeding crossbred cows following intrauterine administration of bacterial modulin. M.V.Sc Thesis (Veterinary Gynaecology \& Obstetrics) Sardarkrushinagar Dantiwada Agricultural University,

Sardarkrushinagar.

Hussain, A.M. and Daniel, R.C.W. (1992). Effects of intrauterine infusion of Escherichia coli endotoxin in normal cows and in cows with endometritis induced by experimental infection with Streptococcus agalactiae. Theriogenology, 37(4): 791-810.

Jain, N.C. (1986). Schalm's Veterinary Haematology. $4^{\text {th }}$ edn. Lea and Febiger, Philadelphia, pp 526-527.

Kasimanickam, R., Duffielda, T.F., Fosterb, R.A., Gartleya, C.J., Lesliea, K.E., Walton, J.S. and Johnsona, W.H. (2004). Endometrial cytology and ultrasonography for the detection of subclinical endometritis in postpartum dairy cows. Theriogenology, 62: 9-23.

Klucinski, W., Targowski, S.P., MiernikDegorska, E. and Winnicka, A. (1990). The phagocytic activity of polymorphonuclear leucocytes isolated from normal uterus and that with experimentally induced inflammation in cows. Journal of Veterinary Medicine Series, 37(7): 506-12.

Kumar, S. (2010). Computation of judicious treatment of endometritis in cows. Ph.D. thesis (Animal Reproduction, Gynaecology and Obstetrics), Sher-eKashmir University of Agricultural Sciences and Technology, Jammu, India.

Modi, L.C., Suthar, B.N., Nakhashi, H.C., Sharma, V.K. and Panchasara, H.H. (2011). Physical characteristics of oestrual cervical mucus and conception rate in repeat breeder Kankrej cattle. Intl. J. Agril. Sci.\& Vet. Med., 5(4): 416-423.

Popov, Y.N. (1969). Diagnosis of occult endometritis in cow (using Whiteside test in cervical mucus). Veterinariya Moscow, 4: 85-87.

Prasad, J.K. (2006). Effect of immunomodulators on endometritis in crossbred cows. Ph.D. thesis (Veterinary Gynaecology and Obstetrics), G. B. Pant University of Agriculture and Technology, Pantnagar. Ravikumar, B.P., Devaraj, M. and Jayakumar, 
K. (2007). Certain biochemical studies on the uterine flushings of normal and endometritis cows. Indian J. Anim. Reprod., 28(2): 101-103.

Roberts, S.J. (1971). Veterinary Obstetrics and Genital Diseases. 2nd edn., Scientific Book Agency, Calcutta, India, pp 36-39.

Saini, P.S. (1993). Studies on etiopathology and modified therapy of bovine endometritis. M.V.Sc. thesis (Veterinary Gynaecology and Obstetrics), Punjab Agricultural University, Ludhiana.

Saini, P.S.,Nanda, A.S., Grewal, A.S. and Singh, J. (1999). Uterine defense modulation for the treatment of repeat breeding due to infectious endometritic in bovines. Indian Journal of Animal Science, 69: 307-309.

Shaktawat, J.S., Saxena, M.S., Prasad, J.K., Singh, C.P. and Jhamb, D. (2006). Escherichia coli lipopoysaccharide; a better alternative therapy of endometritis in crossbred cows. Indian Journal of Animal Reproduction, 27(2): 40-44.

Singh J. (1996). Studies on uterine defence modulation and its therapeutic importance in repeat breeding cows. Ph.D. thesis (Veterinary Gynaecology and Obstetrics), Punjab Agricultural University, Ludhiana.

Singh, G. (1991). Studies on incidence of various reproductive disorders in bovines with special reference to mycotic infections in repeat breeding animals. M.V.Sc. thesis, Punjab Agricultural University, Ludhiana, India.

Singh, J., Dhaliwal, G.S., Nanda, A.S., Arora, A.K. and Pangaonkar, G.R. (2001). Dynamics of uterine microflora in cows suffering from endomeritis following intrauterine administration of Escherichia coli lipopolysaccharide. Indian Journal of Animal Science, 71(12): 1156-1158.

Singh, J., Sidhu, S.S., Dhaliwal, G.S., Pangaonkar, G.R., Nanda, A. S. and Grewal, A.S. (2000). Effectiveness of lipopolysaccharide as an intrauterine immunomodulator in curing bacterial endometritis in repeat breeding croosbred cows. Journal of Animal Reproduction Science, 59: 159-166.

Singh, S. (2016). Phytotherapeutic measures for endometritis in crossbred cows. M.V.Sc \&A.H thesis. Nanaji Deshmukh Veterinary Science University, Jabalpur, India.

Snedecor, G.W. and Cochran, W.G. (1980). Statistical Methods, $14^{\text {th }}$ edn. Oxford and IBH Publishing House, New Delhi, India.

Sudarshan Kumar, Bhardwaz, A. and Srivastava, A.K. (2015). Whiteside testa field test on the cervical mucus of cows for diagnosis of endometritis. Intas Polivet, 16(2): 207-213.

\section{How to cite this article:}

Bhardwaz, Anavil, S.P. Nema, S.S. Mahour, Bagati, Sreshti and Kumar and Sudershan. 2018. Immunomodulatory Effects of LPS (E. coli lipopolysaccharide) in Infectious Repeat Breeder Crossbred Cows. Int.J.Curr.Microbiol.App.Sci. 7(11): 2664-2669. doi: https://doi.org/10.20546/ijcmas.2018.711.304 